\title{
The effect of beef production system on proximate composition and fatty acid profile of three beef muscles
}

\author{
E. Moholisa ${ }^{1 \#}$, P. E. Strydom ${ }^{1,2 \#}$ \& A. Hugo ${ }^{3}$ \\ ${ }_{1}^{1}$ Animal Production Institute, Agricultural Research Council, Private Bag X2, Irene, South Africa \\ ${ }^{2}$ Department of Animal Sciences, Stellenbosch University, Stellenbosch 7602,South Africa \\ ${ }^{3}$ Department of Microbial, Biochemical and Food Biotechnology, University of Free-State, Bloemfontein, South \\ Africa
}

(Received 18 September 2017; Accepted 15 December 2017; First published online 22 December 2017)

\begin{abstract}
Copyright resides with the authors in terms of the Creative Commons Attribution 4.0 South African Licence.
See: http://creativecommons.org/licenses/by/4.0/za

Condition of use: The user may copy, distribute, transmit and adapt the work, but must recognise the authors and the South African Journal of Animal Science.
\end{abstract}

\begin{abstract}
In this study the effects of animal age combined with feeding regime and the utilisation of a betaagonist (within a grain-fed system) on proximate composition and fatty acid profile of $M$. longissimus lumborum (LL), M. biceps femoris (BF), and M. semitendinosus (ST) were determined. Eighty Bonsmara steers consisting of A-age (0 permanent incisors) grain-fed (AC) and grain-fed supplemented with a betaagonist, zilpaterol $(A Z)(n=20)$ grass-fed AB-age (1 - 2 permanent incisors; AB) $(n=20)$, and B-age $(3-6$ permanent incisors; B) $(n=20)$ animals were used. These four groups are representative of cattle slaughtered in South Africa and were treated as four production systems. The chemical composition of all three muscles showed that zilpaterol increased protein and reduced muscle fat contents of meat. All the muscles of both grass-fed groups ( $A B$ and $B$ ) had significantly higher content of certain desirable fatty acids (FAs) such as conjugated linoleic acid (CLA), omega-3 (n-3) FAs, branched chain saturated phytanic acid, and a lower omega-6/omega-3 (n-6/n-3) ratio than the two grain-fed groups (AC and AZ). The FA composition of grain-fed beef muscle was generally not influenced by the use of zilpaterol except for a tendency towards higher $n-6$ polyunsaturated fatty acid (PUFA) in beta-agonist produced beef. This was mainly due to higher levels of linoleic acid in LL and ST muscles and higher CLA in BF muscle of AZ animals. Phytanic acid was also higher in BF muscle of the AZ group compared to AC. Differences in animal age among grass-fed animals ( $A B$ vs. B) had minimal effect on FA composition of grass-fed beef. We can conclude that differences in FA composition of the three muscles are influenced mainly by feeding regime and less by differences in production factors within feeding regimes.
\end{abstract}

Keywords: Animal age, grain feeding, grass feeding, zilpaterol

\#Corresponding authors: moholisae1@arc.agric.za, pstrydom@arc.agric.za

\section{Introduction}

Research on the nutritional characteristics of beef has become increasingly important for the beef industry due to growing consumer interest in healthy diets. Nutritional characteristics of beef can be influenced by production factors such as animal age, feeding regime, growth enhancers and carcass condition at slaughter. There is abundant evidence that type of diet (grass- vs. grain-fed) influences the proximate and fatty acid composition of beef (Daley et al., 2010; De Freitas et al., 2014). Beef from grass-fed animals is often reported as a healthier product than grain-fed beef owing to its lower fat content and more desirable fatty acid profile. Most results show that grass-fed beef has a higher content of CLA, n-3 PUFAs, polyunsaturated to saturated ratio $(P / S)$, and lower $n-6 / n-3$ ratios, as well as lower content of saturated fatty acids (SFAs) and n-6 PUFAs than grain-fed beef (De la Fuente et al., 2009; Daley et al., 2010; Noviandi et al., 2012; De Freitas et al., 2014). Higher content of SFA in meat has traditionally been associated with deleterious human health effects (Whetsell, 2003), although a recent epidemiological study indicated that the association of SFAs with adverse health effects may be debateable (Ruiz-Núñez et al., 2016).

Animal age may differ between grain- and grass-fed based systems but also within these systems as reflected in grass-fed systems where slaughter ages may vary depending on the specific production aims. Muscle fatness may increase along with the age of the animal, which in turn affects the fatty acid 
composition of the meat (Warren et al., 2008). Warren et al. (2008) showed that higher fat levels in meat is accompanied by a higher SFA \% and a lower PUFA \%.

Growth promotants, such as zilpaterol, increase protein and/or decrease fat content of beef (Leheska et al., 2009; Kellermeier et al., 2009; Johnson et al., 2013; Antonelo et al., 2017), which would be beneficial in terms of the nutritional value of meat form a health point of view. Zilpaterol is an approved beta-adrenergic agonistand is used in beef cattle to promote growth and improve feed efficiency (Lean et al., 2014). It is registered in more than 15 countries and is used in South African, Mexican, American (USA) and Canadian feed lots but have never been permitted in Europe (Kuiper et al., 1998; Johnson et al., 2013; Antonelo et al., 2017). The decrease in carcass fat content may also influence the fatty acid profile of fat in the muscle and other fat depots.

Muscles differ in fat content and in fatty acid composition (De Smet et al., 2004). These differences likely result from variations in muscle fibre composition (Enser et al., 1998). According to the review of Wood et al. (2003), red fibres have higher proportion of phospholipids than white muscle fibres and therefore a higher percentage of PUFA. However, De Smet et al. (2004) pointed out that fibre type differences explained variation in several quality traits among muscles but fatty acid composition was not among these traits and other factors may play a more prominent role.

The objective of this study was to investigate the extent to which production systems can affect proximate composition and fatty acid profile of beef with emphasis on the effects ofthe use of beta agonists, variation in animal age, and feeding regime within different production system.

\section{Material and methods}

The procedures involved in sourcing, transport, feeding and slaughtering of the animals used in this study were approved by the Animal Ethics Committee of the ARC (Certificate number: APIEC11/030).

The study consisted of two grass-fed and two grain-fed groups that were further divided into two treatment groups each. For the grass-fed groups, forty $(n=40)$ Bonsmara steers were sourced from farmers involved in oxen production. The steers were raised in the Northern Cape Province of South Africa, between the southern latitudes $26^{\circ} 30^{\prime}$ and $26^{\circ} 35^{\prime}$ and the eastern longitudes $22^{\circ} 30^{\prime}$ and $22^{\circ} 35^{\prime}$ which receives an annual precipitation of $300 \mathrm{~mm}$. The average daily maximum and minimum temperature for this region is 38 ${ }^{\circ} \mathrm{C}$ and $19{ }^{\circ} \mathrm{C}$ in January and $23^{\circ} \mathrm{C}$ and $2{ }^{\circ} \mathrm{C}$ in July (Anonymous, 2017a). The vegetation in this area is described as Kalahari Thornveld Proper (Acocks, 1975) with grazing mainly consisting of Schmidtia pappophroides, Anthephora pubescens and Stipagrostis uniplumis. The most common trees of which the seeds and or leaves may also occasionally be browsed are Boscia albitruncaand Vachellia erioloba. The cattle received a summer lick (October - March) at $100 \mathrm{~g} /$ animal/day consisting of $60 \mathrm{~g}$ each of calcium and phosphorus per $\mathrm{kg}, 120 \mathrm{~g}$ salt $(\mathrm{NaCl})$ and trace elements (Mn, Se, $\mathrm{Zn}, \mathrm{Co}, \mathrm{Cu}, \mathrm{I}, \mathrm{Fe})$ in micro amounts and Vitamin A (40 000 IU / kg)(P6 Phosphate lick, 8211, Feedpro Animal Nutrition, Vryburg, South Africa). From April to September, a winter lick consisting of proteins and minerals (Feedpro 40, Feedpro Animal Nutrition, Vryburg, South Africa) was supplied at $500 \mathrm{~g} / \mathrm{animal} /$ day. Animals were selected as market-ready by visual appraisal of body fat condition (body condition score 4 out of 5 ). Dentition was verified during selection of the animals so that two age groups ( $n=20 /$ group) could be selected according to permanent incisors (p.i.), namely $A B$ (1-2 p.i.) and $B$ (3-6 p.i.) based on the beef carcass classification system of South Africa (Government notice No. R342, 1999).

The weaner calves selected for the two grain-fed groups were raised in the same area as the grassfed animals. Forty (40) weaner (9 to 11 months; $\sim 220 \mathrm{~kg}$ ) Bonsmara steers were raised in a commercial feedlot (A-age, Oincisors). These animals were implanted with Ralgro (36 mg zeranol; Schering-Plough, South Africa) and re-implanted with Revalor-S (140 mg trenbolone acetate and $28 \mathrm{mg}$ beta-oestradiol; Intervet, South Africa) 49 days later. The animals received a high concentrate commercial diet (12 MJ/kg, $135 \mathrm{~g} / \mathrm{kg}$ protein on dry matter basis; (Table 1 ). Twenty (20) grain-fed animals received no beta-agonist (AC), while the remaining 20 (AZ) were supplemented with the beta-agonist, zilpaterol hydrochloride $(\mathrm{ZH})$ (Intervet/Schering-Plough Animal Health, South Africa), at $0.15 \mathrm{mg} / \mathrm{kg}$ live weight for the final 30 days on feed plus a four-day withdrawal period before slaughter. By considering the average daily feed consumption of the animals during the last 30 days on feed, $8.3 \mathrm{mg} \mathrm{ZH} / \mathrm{kg}$ feed (dry matter) was mixed into each batch of feed so that the consumption of $\mathrm{ZH}$ was between $60-90 \mathrm{mg}$ per animal per day according to the permitted range prescribed by the product registration specifications (Anonymous, 2017b). Animals of the grain-fed groups had no p.i. and were fed a commercial diet. 
Table 1 Feed ingredients (\%) and nutritional composition $\left(\mathrm{g} \mathrm{kg}^{-1} \mathrm{DM}\right.$ unless stated otherwise) of the finishing diet of two grain-fed groups

\begin{tabular}{|c|c|c|}
\hline Feed ingredient & $A C^{1}$ & $A Z^{2}$ \\
\hline \multicolumn{3}{|l|}{ Composition of diet: } \\
\hline Hominy chop & 62.00 & 62.00 \\
\hline Wheat bran & 15.00 & 15.00 \\
\hline Molasses meal & 10.00 & 10.00 \\
\hline Cotton $\mathrm{OCM}^{3}$ & 5.00 & 5.00 \\
\hline Grass Hay & 4.50 & 4.50 \\
\hline Feedlime & 1.60 & 1.60 \\
\hline Urea & 1.30 & 1.30 \\
\hline Salt & 0.50 & 0.50 \\
\hline Premix $^{4}$ & 0.10 & 0.10 \\
\hline Zilpaterol HCL $\mathrm{mg} \mathrm{kg}^{-1}$ & 0.00 & 8.30 \\
\hline \multicolumn{3}{|l|}{ Nutrient composition } \\
\hline Dry matter & 873.3 & 873.3 \\
\hline Crude protein & 149.2 & 149.2 \\
\hline Fat & 63.4 & 63.4 \\
\hline $\mathrm{NDF}^{5}$ & 444.8 & 444.8 \\
\hline Crude fibre & 95.8 & 95.8 \\
\hline $\mathrm{ME}^{6}\left(\mathrm{MJ} \mathrm{kg}^{-1} \mathrm{DM}\right)$ & 11.4 & 11.4 \\
\hline Starch & 278.4 & 278.5 \\
\hline Calcium & 7.3 & 7.3 \\
\hline$P$ & 5.2 & 5.2 \\
\hline
\end{tabular}

${ }^{1}$ AC: Treatment without Zilpaterol Hydrochloride (ZH) in diet, animals had zero p.i.

${ }^{2}$ AZ: Treatment with $\mathrm{ZH}$ in diet. $\mathrm{ZH}$ only supplemented for the last 30 on feed, with four days withdrawal before slaughter; animals had zero p.i.

${ }^{3}$ OCM: oil cake meal

${ }_{5}^{4}$ Premix containing: $6 \times 10^{6} \mathrm{IU}$ vitamin A, $3 \mathrm{~g}$ vit B1, $3.5 \mathrm{~g}, 30 \mathrm{~g}$ iron, $12 \mathrm{~g} \mathrm{Cu}, 50 \mathrm{~g}$, Monensin included at $33 \mathrm{mg} \mathrm{kg}^{-1}$ feed

${ }^{5}$ NDF: Neutral detergent fibre

${ }^{6} \mathrm{ME}$ : Metabolisable energy estimated from gross energy (NRC, 1996).

The animals were slaughtered at the abattoir of the Animal Production Institute of the Agricultural Research Council (ARC) Irene, Pretoria. All animals were transported to the abattoir the day before slaughter and kept in lairages overnight $(\sim 18 \mathrm{~h})$ with access to fresh water. The carcasses were chilled at 2 ${ }^{\circ} \mathrm{C}$ (entry and final room temperature) before sampling the day after slaughter. The M. longissimus lumborum (LL; $1^{\text {st }}$ to $5^{\text {th }}$ lumbar vertebrae), M. semitendinosus (ST: whole cut) and M. biceps femoris (BF: whole cut), of each carcass side were sampled and divided into two sub-samples for proximate analyses and fatty acid analyses, respectively.

For proximate analyses and fatty acid profiles two portions of respectively $200 \mathrm{~g}$ and $50 \mathrm{~g}$ were used after all visible fat was removed. Protein, fat, moisture and ash contents of each muscle were measured according to the methods described by the Association of Official Analytical Chemists (AOAC, 1990). For preparation prior to proximate analyses, samples are freeze-dried, stabilized and milled (ground). Samples are weighed before and after freeze-drying and then samples are oven-dried at $105{ }^{\circ} \mathrm{C}$ for 16 hours to determine moisture content (weight loss due to freeze- and oven-drying).

In preparation for fatty acids analysis, extraction of total lipids from each muscle $( \pm 5 \mathrm{~g})$ was performed quantitatively according to Folch et al. (1957), using chloroform and methanol in a ratio of 2:1. Butylated hydroxytoluene (BHT) was added to the chloroform:methanol mixture as an antioxidant, at a concentration of $0.001 \%$. The extracts were dried under vacuum in a rotary evaporator and further dried in a vacuum oven at $50{ }^{\circ} \mathrm{C}$ for 3 hours, with phosphorus pentoxide as moisture adsorbent. Total lipids $( \pm 30 \mathrm{mg})$ from intramuscular fat (IMF) were converted to methyl esters, by base-catalysed transesterification with sodium 
methoxide $(0.5 \mathrm{M}$ solution in anhydrous methanol), in order to avoid conjugated linoleic acid (CLA) isomerisation, during 2 hours at $30^{\circ} \mathrm{C}$ (Park et al., 2001). Fatty acid methyl esters (FAME) were quantified, using a Varian 430 flame ionization gas chromatograph (GC), with a fused silica capillary column (Chrompack CPSIL 88, $100 \mathrm{~m}$ length, $0.25 \mathrm{~mm} \mathrm{ID,} 0.2 \mu \mathrm{m}$ film thicknesses). Analysis was performed using an initial isothermic period $\left(40{ }^{\circ} \mathrm{C}\right.$ for $2 \mathrm{~min}$ ). Thereafter, temperature was increased at a rate of $4{ }^{\circ} \mathrm{C} / \mathrm{min}$ to $230^{\circ} \mathrm{C}$. Finally an isothermic period of $230^{\circ} \mathrm{C}$ for 10 min followed. Fatty acid methyl esters, in $\mathrm{n}$-hexane $(1$ $\mu \mathrm{l})$, were injected into the column, using a Varian CP-8400 autosampler. The injection port and detector were both maintained at $250{ }^{\circ} \mathrm{C}$. Hydrogen, at $45 \mathrm{psi}$, functioned as the carrier gas and nitrogen was employed as the makeup gas. Galaxy Chromatography Data System Software recorded the chromatograms. Identification of sample FAME was made by comparing the relative retention times of FAME peaks from samples, with those of standards obtained from Supelco (Supelco 37 Component Fame Mix 47885-U, Sigma-Aldrich Aston Manor, Pretoria, South Africa). Conjugated linoleic acid standards were obtained from Matreya Inc. (Pleasant Gap, Unites States) and phytanic acid standard was obtained from Sigma (P3819-5MG). These standards included: cis-9, trans-11and trans-10, cis-12 C18:2 isomers. Nonadecanoic acid (C19:0) (SIGMA N553377 $1 \mathrm{G})$ was used as the internal standard to improve quantitative FAME estimation.

In order to determine the health property differences among the four treatment groups, fatty acid data were used to calculate the following ratios of FAs: total SFAs;MUFAs; PUFAs; P/S; omega-6; omega-3; and the ratio of omega- 6 to omega-3 (n-6)/(n-3) FAs. Atherogenicity index (Al) was calculated as:

$$
\mathrm{Al}=(\mathrm{C} 12: 0+4 \times \mathrm{C} 14: 0+\mathrm{C16}: 0) /(\text { MUFA }+ \text { PUFA) (Chilliard et al., 2003). }
$$

Data were subjected to an analysis of variance with treatment group ( $A C, A Z, A B$ and $B$ ) as single factor using the statistical program GenStat ${ }^{\circledR}$ (Payne et al., 2007). The data of each muscle were analysed separately. The Shapiro-Wilk's test was performed on the standardised residuals to test for deviations from normality. Tukey Kramer multiple comparison test was used to separate group means and they were considered to be significantly different when $P \leq 0.05$.

\section{Results and Discussion}

Table 2 summarises the live animal and carcass characteristics. Mean carcass weights of $A C, A Z$, and $B$ groups were between 30 and $44 \mathrm{~kg}$ higher than those of the $A B$ group $(P<0.001)$. No accurate age could be given to grain-fed animals, but considering that most animals in feedlots are fed for $\sim 100$ days and enter the feedlot at 8 - 9 months of age, the animals of $A C$ and $A Z$ would have been $\sim 12$ months at slaughter. The $B$ group animals were 12 months older on average than the $A B$ group animals. Based on fat code, carcasses of the two grass-fed groups were leaner than the grain-fed groups, while $A Z$ carcasses were generally leaner than AC carcasses.

Table 2 General description of live animal and carcass properties of the four treatment groups

\begin{tabular}{|c|c|c|c|c|c|c|}
\hline Treatment & $A C^{1}$ & $A Z^{2}$ & $A B^{3}$ & $B^{4}$ & MSE & $\begin{array}{c}P \text { - } \\
\text { value }\end{array}$ \\
\hline Live weight (farm) & $513^{\mathrm{ab}}$ & $535^{\mathrm{bc}}$ & $499^{\mathrm{a}}$ & $562^{\mathrm{c}}$ & 5.97 & $<0.001$ \\
\hline Carcass weight $(\mathrm{kg})$ & $297^{\mathrm{b}}$ & $311^{\mathrm{b}}$ & $267^{\mathrm{a}}$ & $302^{b}$ & 4.21 & $<0.001$ \\
\hline Number of permanent incisors & $0(100 \%)$ & $0(100 \%)$ & $\begin{array}{c}2 \\
(100 \%)\end{array}$ & $\begin{array}{c}3(5 \%), 4(65 \%), 5(10 \%), \\
6(20 \%)\end{array}$ & & \\
\hline Mean age (months) & $\sim 12$ & $\sim 12$ & 31 & 43 & & \\
\hline Fat code ${ }^{5}$ (frequencies) & $\begin{array}{c}3(67 \%) 4 \\
(33 \%)\end{array}$ & $\begin{array}{c}2(13 \%), 3 \\
(87 \%)\end{array}$ & $\begin{array}{c}2 \\
(100 \%)\end{array}$ & $2(100 \%)$ & & \\
\hline
\end{tabular}

\footnotetext{
${ }^{1} \mathrm{AC}:$ Treatment without Zilpaterol Hydrochloride $(\mathrm{ZH})$ in diet, animals had zero p.i.

${ }^{2}$ AZ: Treatment with ZH in diet. ZH only supplemented for the last 30 on feed, with four days withdrawal before slaughter; animals had zero p.i.

${ }^{3} A B:$ Grass-fed steers with 1-2 p.i.

${ }^{4} \mathrm{~B}$ : Grass-fed steers with 3-6 p.i.

${ }^{5}$ Fat code: 1-very lean, 2-lean, 3-medium, 4-fat (Government Notice No. R.342 of 1999).

${ }^{a, b}$ within a row with different superscripts differ significantly, MSE $=$ Standard error of mean.
} 
Production system had a significant effect on proximate composition of the three muscles, although actual differences were small in magnitude (Table 3). Moisture content was higher, and dry matter lower in the grass-fed $A B$ and $B$ groups than in the grain-fed $A Z$ group for all three muscles $(P<0.001)$. Moisture and dry matter content was the same for $L L$ muscle of $A Z$ and $A C$, while similar values for moisture and dry matter were recorded for $S T$ and $B F$ muscles of the $A C, A B$ and $B$ groups. The higher dry matter content of grain-fed muscleswere either afunction of higher protein (AZ) or higher muscle fat (AC) in muscle of grain-fed carcasses as was reported by Pflanzer and De Felício (2011).The AC LL muscle recorded higher fat than all other groups $(P<0.001)$, but for the BF muscle the treatment effect was only significant $(P=0.021)$ between $\mathrm{AC}$ and $\mathrm{AB}$.The higher muscle fat content corresponds with the fatter carcasses in the AC group (Table 2) as a result of their high energy diet compared to grass-fed animals (Silva et al., 2010).

Table 3 Effect of production system on proximate composition of beef $M$. longissimus lumborum, $M$. semitendinosus and $M$. biceps femoris

\begin{tabular}{|c|c|c|c|c|c|c|}
\hline Treatment & $A C^{1}$ & $A \mathbf{Z}^{2}$ & $A B^{3}$ & $\mathrm{~B}^{4}$ & MSE & $P$-value \\
\hline \multicolumn{7}{|c|}{ M. longissimus lumborum } \\
\hline$\%$ Dry matter & $25.2^{\mathrm{b}}$ & $25.2^{\mathrm{b}}$ & $23.6^{a}$ & $24.2^{\mathrm{a}}$ & 0.76 & $<0.001$ \\
\hline$\%$ Ash & $0.97^{\mathrm{a}}$ & $1.13^{\mathrm{b}}$ & $1.16^{\mathrm{b}}$ & $1.21^{b}$ & 0.03 & $<0.001$ \\
\hline$\%$ Crude protein ${ }^{5}$ & $21.1^{\mathrm{a}}$ & $22.4^{\mathrm{b}}$ & $21.1^{\mathrm{a}}$ & $21.3^{\mathrm{a}}$ & 0.21 & $<0.001$ \\
\hline$\%$ Crude fat $^{5}$ & $3.12^{\mathrm{b}}$ & $1.65^{\mathrm{a}}$ & $1.36^{\mathrm{a}}$ & $1.65^{\mathrm{a}}$ & 0.18 & $<0.001$ \\
\hline$\%$ Moisture & $74.8^{\mathrm{a}}$ & $74.8^{\mathrm{a}}$ & $76.4^{\mathrm{b}}$ & $75.8^{b}$ & 0.31 & $<0.001$ \\
\hline \multicolumn{7}{|l|}{ M. semitendinosus } \\
\hline$\%$ Dry matter & $22.8^{\mathrm{a}}$ & $23.8^{\mathrm{b}}$ & $22.9^{\mathrm{c}}$ & $22.4^{\mathrm{bc}}$ & 0.21 & $<0.001$ \\
\hline$\%$ Ash & $1.03^{\mathrm{a}}$ & $1.06^{\mathrm{a}}$ & $1.13^{\mathrm{b}}$ & $1.08^{\mathrm{ab}}$ & 0.02 & $<0.001$ \\
\hline$\%$ Crude protein ${ }^{5}$ & $20.3^{\mathrm{c}}$ & $21.5^{\mathrm{c}}$ & $20.7^{b}$ & $20.1^{\mathrm{a}}$ & 0.16 & $<0.001$ \\
\hline$\%$ Crude fat $^{5}$ & 1.43 & 1.18 & 1.12 & 1.19 & 0.16 & 0.149 \\
\hline$\%$ Moisture & $77.2^{\mathrm{b}}$ & $76.2^{\mathrm{a}}$ & $77.1^{\mathrm{b}}$ & $77.6^{\mathrm{b}}$ & 0.21 & $<0.001$ \\
\hline \multicolumn{7}{|l|}{ M. biceps femoris } \\
\hline$\%$ Dry matter & $22.5^{\mathrm{b}}$ & $23.9^{\mathrm{a}}$ & $22.3^{\mathrm{b}}$ & $22.5^{\mathrm{b}}$ & 0.37 & $<0.001$ \\
\hline$\%$ Ash & $0.96^{\mathrm{a}}$ & $1.05^{\mathrm{C}}$ & $1.03^{\mathrm{bc}}$ & $1.01^{b}$ & 0.01 & $<0.001$ \\
\hline$\%$ Crude protein ${ }^{5}$ & $20.1^{a}$ & $21.5^{\mathrm{b}}$ & $20.2^{\mathrm{a}}$ & $20.3^{a}$ & 0.16 & $<0.001$ \\
\hline$\%$ Crude fat $^{5}$ & $1.46^{\mathrm{b}}$ & $1.34^{\mathrm{b}}$ & $1.01^{\mathrm{a}}$ & $1.25^{\mathrm{ab}}$ & 0.11 & $<0.021$ \\
\hline$\%$ Moisture & $77.5^{\mathrm{b}}$ & $76.1^{a}$ & $77.7^{\mathrm{b}}$ & $77.5^{\mathrm{b}}$ & 0.19 & $<0.001$ \\
\hline
\end{tabular}

${ }^{1} \mathrm{AC}:$ Treatment without Zilpaterol Hydrochloride $(\mathrm{ZH})$ in diet, animals had zero p.i.

${ }^{2}$ AZ: Treatment with ZH in diet. ZH only supplemented for the last 30 on feed, with four days withdrawal before slaughter; animals had zero p.i.

${ }^{3} A B:$ Grass-fed steers with 1-2 p.i.

${ }^{4} \mathrm{~B}$ : Grass-fed steers with 3-6 p.i.

${ }^{5}$ Crude protein (N x 6.25), crude fat - AOAC (1990)

a,b,c within a row with different superscripts differ significantly, MSE=Standard error of mean

Strydom et al. (2009) reported lower fat levels in LL and ST muscles and higher moisture levels in LL of zilpaterol-treated steers, but no differences in protein levels between zilpaterol treated and control animals. In agreement with our study, Leheska et al. (2009) found higher protein in soft tissue of zilpaterol treated steers and heifers, but only trends towards lower fat and higher moisture levels in treated heifers but not steers. In both studies differences between treatments were also small $(<1$ percentage unit). According to a meta-analysis conducted by Lean et al. (2014), there is no consensus regarding the exact mechanism that different beta-adrenergic agonists exert on muscle and fat tissue that may result in changes in the proportions of these tissues. Leheska et al. (2009) suggested that zilpaterol increases muscle deposition at the expense of fat deposition, by directing nutrients towards muscle and away from fat deposition, thereby increasing muscle hypertrophy. Parr et al. (2014) found that serum non-esterified fatty acid levels (NEFA) of zilpaterol fed animals was higher indicating triglyceride breakdown. However, in earlier studies (Miller et al., 
2012) they could not show any de novo effects of zilpaterol on carcass fat tissue (muscle or subcutaneous fat) and suspected effects on other fat depots (intestinal fats).

The effect of beta agonists on fat could also be muscle fibre related. Zilpaterol, and other betaagonists, increase the size and proportion of white or fast glycolytic muscle fibres (Strydom et al., 2009). Scollan et al. (2006) explained that the shift in fiber types from slower oxidative types to faster glycolytic affect the animal's ability to accumulate fat since oxidative muscles have greater ability to deposit fat. The differential response of muscles to beta-agonists was also reported by Dawson et al. (1990) who observed that ST compared to LL and vastus lateralis showed no significant differences in protein content and they related this to differences in fibre type composition of the muscles which will influence their response to betaagonists.

Warren et al. (2008) observed that muscle fat content increased as animals get older, regardless of feeding regimen. However in our study age at slaughter did not influence IMF content in the grass-fed groups $(A B$ and $B)$ and muscle fat in these groups tended to be lower or similar to the grain-fed groups (Table 3). Schönfeldt et al. (2010) agreed with our results and could not find differences in muscle fat content among A (12 months old), B ( $>36$ months + ), and C age ( $>72$ months) classes of beef cuts sourced from the commercial South African market when their total carcass fat levels were similar. The lack of differences in IMF between the $A B$ and $B$ age groups in our study could probably be explained by adipocyte physiology since the $A B$ group consisted of younger steers while the $B$ group was older steers. According to Harper and Pethick (2004), advancing age does not influence all stem cells with adipogenic potential. Germ stem cells and some of the expression of the transcriptional factors essential for adipogenesis may decline in older animals. As a result older animals may be less able to support adipogenesis even if they have genetic predisposition to fatness and a high-energy diet conducive to fatness. The actual average age difference between $A B$ and $B$ in our study was 10 months and it is possible that the difference in age was not sufficient to cause any effects on fat deposition mechanisms.

The effects of production system on muscle content of fatty acid groups and individual fatty acids of three muscles are presented in Table 4 and Table 5, respectively. The fatty acid profile of beef cannot be generalised due interacting factors such as breed, level of fatness, type or location of fat depot, animal age and diet (De Smet et al., 2004). The low muscle fat content as reflected in Table 3 should also be considered in the interpretation of fatty acid proportions across treatment groups and muscles. Feeding regime showed a larger effect on the fatty acid profiles than zilpaterol and animal age among production systems. It should also be added that animal age was confounded with feeding regime (grain-fed AC and AZ vs grass-fed AB and $B$ ) and did not show clear effects when compared within feeding regime (grass-fed $A B$ and $B$ ). The various treatments also affected muscles differently.

The ST muscle of the AZ group had lower total SFAs compared to AB and B (Table 4), which was mostly contributed by $(P<0.001)$ lower palmitic acid $(C 16: 0)$ in $A Z$ group compared to the two grass-fed groups (Table 5). In contrast, the grass-fed B group had lower percentages of stearic acid (C18:0) than that of $A Z$ in the $L L$ muscle and that of $A C$ in the $B F$ muscle, respectively.Most minor individual SFAs (pentadecyclic $(\mathrm{C} 15: 0)$, heptadecanoic $(\mathrm{C} 17: 0)$ and eicosenoic $(\mathrm{C} 20: 0))$ were lower $(P<0.001)$ in both grainfed groups than in the grass-fed groups for all three muscles. Only myristic acid (C14:0) which accounted for at least $3 \%$ of the total FAs was higher in the grain-fed groups compared to the grass-fed AB but not to the grass-fed B group in all three muscles. The tendency towards higher C16:0 and lower C18:0 in grass-fed groups contrasts the review of Daley et al. (2010). According to this study grass-fed beef has lower proportion of hypercholesterolaemic $\mathrm{C} 16: 0$ and a trend towards a higher proportion of neutral cholesterolaemic C18:0. However, Daley et al. (2010) also emphasised that the overall concentration of total SFAs in muscle fat is not consistently different between grain and grass feeding which generally agrees with our results.

The ST muscle of the AZ group had lower total SFAs compared to $A B$ and $B$ (Table 4), which was mostly contributed by $(P<0.001)$ lower palmitic acid $(C 16: 0)$ in $A Z$ group compared to the two grass-fed groups (Table 5). In contrast, the grass-fed $B$ group had lower percentages of stearic acid (C18:0) than that of $A Z$ in the $L L$ muscle and that of $A C$ in the BF muscle, respectively. Most minor individual SFAs (pentadecyclic $(\mathrm{C} 15: 0)$, heptadecanoic $(\mathrm{C} 17: 0)$, and eicosenoic $(\mathrm{C} 20: 0))$ were lower $(P<0.001)$ in both grainfed groups compared to the grass-fed groups for all three muscles. Only myristic acid $(\mathrm{C} 14: 0)$ which accounted for at least $3 \%$ of the total FAs was higher in the grain-fed groups compared to the grass-fed $A B$ but not to the grass-fed B group in all three muscles. The tendency towards higher C16:0 and lower C18:0 in grass-fed groups contrasts the review of Daley et al. (2010). According to this study grass-fed beef has lower proportion of hypercholesterolaemic $\mathrm{C} 16: 0$ and a trend towards a higher proportion of neutral cholesterolaemic C18:0. However, Daley et al. (2010) also emphasised that the overall concentration of total SFAs in muscle fat is not consistently different between grain and grass feeding which generally agrees with our results. 
Table 4 Effect of production system onratios fatty acid groups of beef $M$. longissimuslumborum, $M$. semitendinosus and $M$. biceps femoris

\begin{tabular}{|c|c|c|c|c|c|c|}
\hline Treatment & $A C^{1}$ & $A Z^{2}$ & $A B^{3}$ & $B^{4}$ & MSE & $P$-value \\
\hline \multicolumn{7}{|c|}{ M. longissimus lumborum } \\
\hline Total SFA & 52.0 & 51.6 & 52.5 & 53.6 & 2.66 & 0.059 \\
\hline Total MUFA & $41.4^{\mathrm{b}}$ & $39.5^{\mathrm{ab}}$ & $38.0^{\mathrm{a}}$ & $38.5^{\mathrm{a}}$ & 2.76 & $<0.001$ \\
\hline Total PUFA & $6.59^{\mathrm{a}}$ & $8.88^{\mathrm{b}}$ & $9.52^{\mathrm{b}}$ & $7.92^{\mathrm{ab}}$ & 2.80 & 0.003 \\
\hline Total n-6 & $5.99^{\mathrm{a}}$ & $8.15^{\mathrm{b}}$ & $5.79^{\mathrm{a}}$ & $4.91^{\mathrm{a}}$ & 2.15 & $<0.001$ \\
\hline Total n-3 & $0.57^{\mathrm{a}}$ & $0.69^{\mathrm{a}}$ & $3.51^{\mathrm{c}}$ & $2.79^{b}$ & 0.79 & $<0.001$ \\
\hline $\mathrm{P} / \mathrm{S}$ & $0.13^{\mathrm{a}}$ & $0.17^{\mathrm{ab}}$ & $0.18^{\mathrm{b}}$ & $0.15^{\mathrm{ab}}$ & 0.06 & 0.012 \\
\hline$n-6 / n-3$ & $15.39^{b}$ & $13.55^{\mathrm{b}}$ & $1.64^{\mathrm{a}}$ & $1.80^{\mathrm{a}}$ & 3.06 & $<0.001$ \\
\hline Atherogenicity Index & $0.92^{\mathrm{ab}}$ & $0.89^{\mathrm{ab}}$ & $0.87^{\mathrm{a}}$ & $0.96^{\mathrm{b}}$ & 0.12 & 0.038 \\
\hline \multicolumn{7}{|l|}{ M. semitendinosus } \\
\hline Total SFA & $48.6^{\mathrm{ab}}$ & $47.4^{\mathrm{a}}$ & $49.6^{b}$ & $50.3^{\mathrm{b}}$ & 2.53 & 0.003 \\
\hline Total MUFA & $41.7^{\mathrm{b}}$ & $40.2^{\mathrm{ab}}$ & $39.1^{\mathrm{a}}$ & $39.8^{\mathrm{a}}$ & 1.97 & 0.002 \\
\hline Total PUFA & $9.70^{\mathrm{a}}$ & $12.4^{\mathrm{b}}$ & $11.4^{\mathrm{ab}}$ & $9.95^{\mathrm{a}}$ & 2.59 & 0.003 \\
\hline Total n-6 & $8.43^{\mathrm{b}}$ & $10.85^{c}$ & $6.61^{\mathrm{a}}$ & $5.83^{a}$ & 1.33 & $<0.001$ \\
\hline Total n-3 & $1.24^{\mathrm{a}}$ & $1.53^{\mathrm{a}}$ & $4.53^{\mathrm{b}}$ & $3.88^{\mathrm{b}}$ & 0.30 & $<0.001$ \\
\hline $\mathrm{P} / \mathrm{S}$ & $0.20^{\mathrm{a}}$ & $0.27^{\mathrm{b}}$ & $0.23^{\mathrm{ab}}$ & $0.20^{\mathrm{a}}$ & 0.04 & 0.003 \\
\hline$n-6 / n-3$ & $8.95^{\mathrm{b}}$ & $8.11^{\mathrm{b}}$ & $1.47^{\mathrm{a}}$ & $1.49^{\mathrm{a}}$ & 1.12 & $<0.001$ \\
\hline Atherogenicity Index & $0.80^{\mathrm{ab}}$ & $0.74^{\mathrm{a}}$ & $0.77^{\mathrm{ab}}$ & $0.82^{\mathrm{b}}$ & 0.08 & 0.045 \\
\hline \multicolumn{7}{|l|}{ M. biceps femoris } \\
\hline Total SFA & 50.1 & 49.0 & 50.5 & 49.5 & 2.60 & 0.235 \\
\hline Total MUFA & 41.1 & 41.3 & 41.0 & 42.0 & 2.39 & 0.497 \\
\hline Total PUFA & 8.82 & 9.82 & 8.54 & 8.53 & 2.49 & 0.346 \\
\hline Total n-6 & $8.01^{b}$ & $8.89^{b}$ & $5.28^{\mathrm{a}}$ & $5.30^{\mathrm{a}}$ & 1.59 & $<0.001$ \\
\hline Total n-3 & $0.79^{\mathrm{a}}$ & $0.83^{\mathrm{a}}$ & $2.98^{\mathrm{b}}$ & $2.94^{\mathrm{b}}$ & 0.69 & $<0.001$ \\
\hline $\mathrm{P} / \mathrm{S}$ & 0.18 & 0.20 & 0.17 & 0.17 & 0.08 & 0.271 \\
\hline$n-6 / n-3$ & $11.4^{\mathrm{b}}$ & $13.6^{\mathrm{b}}$ & $1.78^{\mathrm{a}}$ & $1.80^{\mathrm{a}}$ & 4.94 & $<0.001$ \\
\hline Atherogenicity Index & 0.83 & 0.81 & 0.81 & 0.82 & 0.12 & 0.931 \\
\hline
\end{tabular}

The LL $(P<0.001)$ and ST $(P<0.003)$ muscles of grain-fed AC animals recorded higher total MUFA content than muscles of both grass-fed groups (AB and $B)$, (Table 4). This effect was mainly due to higher elaidic (C18:1t9) and oleic (C18:1c9) acids in these muscles of the AC group (Table 5). Grain feeding is known to present higher levels of C18:1 FAs as a result of incomplete biohydrogenation of dietary PUFAs in the rumen (Noviandi et al., 2012). Another reason for higher percentages of individual C18:1t9 and C18:1c9 could be the higher muscle fat content of the AC group (Table 3) as supported by Smith et al. (2009) and Shirouchi et al. (2013), although this would not apply to the BF muscle.

Total PUFA content was higher in the LL and ST muscles of the $A Z$ group, and closer to that of the $A B$ group, compared to that of $A C$ group (Table 4). This effect was largely as a result of higher $(P<0.005)$ linoleic acid (C18:2c9 (n-6)) observed in these muscles of the AZ group (Table 5). Subsequently, the P/S ratio was higher $(P=0.003)$ in AZ ST muscles with similar trends in the other two muscles when compared 
Table 5 Effect of production system on fatty acid composition of intramuscular fat of beef $M$. longissimus lumborum, M. semitendinosus and M. biceps femoris

\begin{tabular}{|c|c|c|c|c|c|c|c|c|c|c|c|c|c|c|c|c|c|c|}
\hline \multirow[b]{2}{*}{ Treatment } & \multicolumn{6}{|c|}{ M.longissimus lumborum } & \multicolumn{6}{|c|}{ M. semitendinosus } & \multicolumn{6}{|c|}{ M. biceps femoris } \\
\hline & $A C^{1}$ & $A Z^{2}$ & $A B^{3}$ & $B^{4}$ & MSE & P-Value & $A C^{1}$ & $A Z^{2}$ & $A B^{3}$ & $B^{4}$ & MSE & P-Value & $A C^{1}$ & $A Z^{2}$ & $A B^{3}$ & $B^{4}$ & MSE & $P$-Value \\
\hline \multicolumn{19}{|c|}{ Fatty acid methyl ester/s (\% of total fatty acids) } \\
\hline $\mathrm{C} 14: 0$ & $3.22^{\mathrm{b}}$ & $3.13^{\mathrm{b}}$ & $2.40^{\mathrm{a}}$ & $2.82^{\mathrm{ab}}$ & 0.53 & $<0.001$ & $2.75^{b}$ & $2.44^{\mathrm{b}}$ & $1.93^{\mathrm{a}}$ & $2.32^{\mathrm{ab}}$ & 0.59 & $<0.001$ & $2.85^{\mathrm{ab}}$ & $3.12^{\mathrm{b}}$ & $2.59^{\mathrm{a}}$ & $2.81^{\mathrm{ab}}$ & 0.38 & 0.008 \\
\hline C14:1c9 & 0.23 & 0.23 & 0.23 & 0.29 & 0.03 & 0.27 & 0.27 & 0.31 & 0.24 & 0.31 & 0.05 & 0.451 & $0.26^{\mathrm{a}}$ & $0.31^{\mathrm{a}}$ & $0.37^{\mathrm{ab}}$ & $0.50^{\mathrm{b}}$ & 0.06 & $<0.001$ \\
\hline $\mathrm{C} 15: 0$ & $0.16^{\mathrm{a}}$ & $0.16^{\mathrm{a}}$ & $0.36^{\mathrm{b}}$ & $0.36^{\mathrm{b}}$ & 0.02 & $<0.001$ & $0.09^{\mathrm{a}}$ & $0.12^{\mathrm{a}}$ & $0.32^{\mathrm{b}}$ & $0.37^{b}$ & 0.02 & $<0.001$ & $0.09^{\mathrm{a}}$ & $0.17^{b}$ & $0.43^{\mathrm{c}}$ & $0.42^{\mathrm{c}}$ & 0.01 & $<0.001$ \\
\hline C16:0 & $30.7^{b}$ & $30.1^{\mathrm{a}}$ & $31.6^{\mathrm{b}}$ & $33.0^{c}$ & 3.85 & $<0.001$ & $30.0^{\mathrm{ab}}$ & $29.0^{\mathrm{a}}$ & $30.7^{b c}$ & $31.3^{c}$ & 0.84 & $<0.001$ & 29.55 & 28.7 & 29.4 & 29.73 & 1.05 & 0.277 \\
\hline C16:1c9 & $2.58^{\mathrm{ab}}$ & $2.38^{\mathrm{a}}$ & $2.82^{\mathrm{bc}}$ & $3.04^{\mathrm{c}}$ & 0.28 & $<0.001$ & $2.75^{a}$ & $2.57^{\mathrm{a}}$ & $2.85^{\mathrm{ab}}$ & $3.20^{\mathrm{b}}$ & 0.43 & $<0.001$ & $2.59^{\mathrm{a}}$ & $2.91^{a}$ & $3.50^{\mathrm{b}}$ & $3.78^{\mathrm{b}}$ & 0.28 & $<0.001$ \\
\hline $\begin{array}{l}\text { C20:0 3,7,11,15tetramethyl } \\
\text { hexadecanoic acid }\end{array}$ & $0.34^{\mathrm{a}}$ & $0.38^{\mathrm{a}}$ & $0.70^{\mathrm{b}}$ & $0.70^{\mathrm{b}}$ & 0.02 & $<0.001$ & $0.27^{\mathrm{a}}$ & $0.27^{\mathrm{a}}$ & $0.65^{\mathrm{b}}$ & $0.71^{b}$ & 0.03 & $<0.001$ & $0.26^{\mathrm{a}}$ & $0.41^{b}$ & $0.85^{\mathrm{c}}$ & $0.85^{\mathrm{c}}$ & 0.02 & $<0.001$ \\
\hline $\mathrm{C} 17: 0$ & $0.66^{\mathrm{a}}$ & $0.68^{a}$ & $0.97^{b}$ & $0.95^{b}$ & 0.03 & $<0.001$ & $0.59^{\mathrm{a}}$ & $0.60^{\mathrm{a}}$ & $0.94^{\mathrm{b}}$ & $0.97^{b}$ & 0.03 & $<0.001$ & $0.65^{\mathrm{a}}$ & $0.73^{\mathrm{a}}$ & $1.03^{b}$ & $0.98^{\mathrm{b}}$ & 0.04 & $<0.001$ \\
\hline C17:1c10 & $0.38^{\mathrm{bc}}$ & $0.42^{c}$ & $0.28^{\mathrm{ab}}$ & $0.24^{\mathrm{a}}$ & 0.03 & $<0.001$ & $0.42^{\mathrm{ab}}$ & $0.52^{\mathrm{b}}$ & $0.38^{\mathrm{ab}}$ & $0.33^{\mathrm{a}}$ & 0.06 & 0.015 & 0.4 & 0.38 & 0.3 & 0.37 & 0.06 & 0.22 \\
\hline $\mathrm{C} 18: 0$ & $16.9^{\mathrm{ab}}$ & $17.2^{\mathrm{b}}$ & $16.4^{\mathrm{ab}}$ & $15.9^{\mathrm{a}}$ & 0.84 & 0.012 & 15 & 15.1 & 15 & 14.6 & 0.91 & 0.694 & $16.66^{\mathrm{b}}$ & $15.75^{\mathrm{ab}}$ & $16.01^{b}$ & $14.56^{\mathrm{a}}$ & 0.86 & $<0.001$ \\
\hline C18:1t9 & $2.08^{\mathrm{b}}$ & $2.35^{\mathrm{b}}$ & $0.47^{\mathrm{a}}$ & $0.67^{\mathrm{a}}$ & 0.91 & $<0.001$ & $1.98^{\mathrm{b}}$ & $1.98^{\mathrm{b}}$ & $0.86^{\mathrm{a}}$ & $0.61^{\mathrm{a}}$ & 0.92 & $<0.001$ & $1.78^{\mathrm{b}}$ & $2.00^{\mathrm{b}}$ & $0.39^{a}$ & $0.35^{\mathrm{a}}$ & 0.8 & $<0.001$ \\
\hline C18:1c9 & $35^{\mathrm{b}}$ & $33.0^{\mathrm{a}}$ & $33.0^{\mathrm{a}}$ & $33.0^{\mathrm{a}}$ & 1.76 & 0.003 & $35.0^{b}$ & $33.4^{\mathrm{a}}$ & $33.4^{\mathrm{a}}$ & $34.0^{\mathrm{ab}}$ & 1.39 & 0.022 & 34.8 & 34.3 & 35.0 & 35.4 & 1.82 & 0.400 \\
\hline C18:1c7 & $1.13^{\mathrm{a}}$ & $1.18^{\mathrm{ab}}$ & $1.32^{\mathrm{b}}$ & $1.26^{\mathrm{ab}}$ & 0.05 & 0.003 & 1.26 & 1.4 & 1.39 & 1.35 & 0.06 & 0.099 & $1.27^{\mathrm{a}}$ & $1.39^{\mathrm{ab}}$ & $1.49^{\mathrm{bc}}$ & $1.56^{\mathrm{c}}$ & 0.07 & $<0.001$ \\
\hline C18:2c9,12 (n-6) & $5.19^{b}$ & $7.14^{\mathrm{c}}$ & $3.84^{\mathrm{a}}$ & $3.33^{\mathrm{a}}$ & 4.13 & $<0.001$ & $6.83^{\mathrm{b}}$ & $8.91^{\mathrm{C}}$ & $4.08^{\mathrm{a}}$ & $3.65^{\mathrm{a}}$ & 3.09 & $<0.001$ & $6.70^{\mathrm{b}}$ & $7.69^{\mathrm{b}}$ & $3.65^{\mathrm{a}}$ & $3.55^{\mathrm{a}}$ & 3.81 & $<0.001$ \\
\hline C20:0 & $0.01^{\mathrm{a}}$ & $0.01^{a}$ & $0.13^{c}$ & $0.08^{b}$ & 0.01 & $<0.001$ & $0.01^{a}$ & $0.01^{\mathrm{a}}$ & $0.05^{b}$ & $0.06^{b}$ & 0.01 & $<0.001$ & $0.01^{\mathrm{a}}$ & $0.01^{a}$ & $0.14^{\mathrm{C}}$ & $0.10^{\mathrm{b}}$ & 0.01 & $<0.001$ \\
\hline C18:3c9,12,15 (n-3) & $0.20^{\mathrm{a}}$ & $0.23^{\mathrm{a}}$ & $1.32^{c}$ & $1.11^{b}$ & 0.1 & $<0.001$ & $0.25^{\mathrm{a}}$ & $0.36^{\mathrm{a}}$ & $1.43^{\mathrm{c}}$ & $1.20^{\mathrm{b}}$ & 0.08 & $<0.001$ & $0.18^{\mathrm{a}}$ & $0.27^{\mathrm{a}}$ & $1.26^{\mathrm{b}}$ & $1.21^{\mathrm{b}}$ & 0.08 & $<0.001$ \\
\hline $\mathrm{C} 18: 2 \mathrm{c} 9, \mathrm{t} 11(\mathrm{n}-7)$ & $0.02^{\mathrm{a}}$ & $0.05^{\mathrm{a}}$ & $0.21^{\mathrm{b}}$ & $0.22^{b}$ & 0.01 & $<0.001$ & $0.02^{\mathrm{a}}$ & $0.07^{\mathrm{a}}$ & $0.22^{\mathrm{b}}$ & $0.25^{\mathrm{b}}$ & 0.01 & $<0.001$ & $0.02^{\mathrm{a}}$ & $0.09^{b}$ & $0.29^{c}$ & $0.29^{c}$ & 0.01 & $<0.001$ \\
\hline $\mathrm{C} 20: 3 \mathrm{c} 11,14,17(\mathrm{n}-3)$ & $0.15^{\mathrm{a}}$ & $0.18^{\mathrm{a}}$ & $0.35^{\mathrm{b}}$ & $0.28^{b}$ & 0.02 & $<0.001$ & $0.32^{\mathrm{a}}$ & $0.34^{\mathrm{ab}}$ & $0.45^{\mathrm{b}}$ & $0.43^{\mathrm{ab}}$ & 0.03 & 0.007 & $0.24^{\mathrm{ab}}$ & $0.20^{\mathrm{a}}$ & $0.30^{\mathrm{b}}$ & $0.30^{\mathrm{b}}$ & 0.02 & 0.002 \\
\hline $\mathrm{C} 20: 4 \mathrm{c} 5,8,11,14(\mathrm{n}-6)$ & $0.80^{\mathrm{a}}$ & $1.01^{\mathrm{a}}$ & $1.95^{\mathrm{b}}$ & $1.58^{b}$ & 0.45 & $<0.001$ & $1.61^{\mathrm{a}}$ & $1.94^{\mathrm{ab}}$ & $2.53^{\mathrm{c}}$ & $2.17^{\mathrm{bc}}$ & 0.72 & $<0.001$ & $1.31^{\mathrm{ab}}$ & $1.20^{\mathrm{a}}$ & $1.63^{\mathrm{ab}}$ & $1.76^{\mathrm{b}}$ & 0.52 & 0.005 \\
\hline $\mathrm{C} 20: 5 \mathrm{c} 5,8,11,14,17(\mathrm{n}-3)$ & $0.06^{\mathrm{a}}$ & $0.07^{\mathrm{a}}$ & $0.73^{\mathrm{c}}$ & $0.53^{b}$ & 0.05 & $<0.001$ & $0.20^{\mathrm{a}}$ & $0.28^{\mathrm{a}}$ & $0.98^{\mathrm{b}}$ & $0.83^{b}$ & 0.08 & $<0.001$ & $0.11^{\mathrm{a}}$ & $0.12^{\mathrm{a}}$ & $0.56^{\mathrm{b}}$ & $0.58^{\mathrm{b}}$ & 0.04 & $<0.001$ \\
\hline $\mathrm{C} 22: 5 \mathrm{c} 7,10,13,16,19(n-3)$ & $0.16^{\mathrm{a}}$ & $0.20^{\mathrm{a}}$ & $1.11^{\mathrm{c}}$ & $0.86^{b}$ & 0.12 & $<0.001$ & $0.46^{\mathrm{a}}$ & $0.55^{\mathrm{a}}$ & $1.62^{\mathrm{b}}$ & $1.37^{\mathrm{b}}$ & 0.31 & $<0.001$ & $0.26^{\mathrm{a}}$ & $0.23^{\mathrm{a}}$ & $0.85^{\mathrm{b}}$ & $0.83^{\mathrm{b}}$ & 0.09 & $<0.001$ \\
\hline $\mathrm{C} 22: 6 \mathrm{c} 4,7,10,13,16,19(\mathrm{n}-3)$ & 0.01 & 0.01 & 0.01 & 0.01 & 0.01 & 0.137 & $0.01^{\mathrm{a}}$ & $0.01^{\mathrm{a}}$ & $0.05^{\mathrm{b}}$ & $0.04^{\mathrm{ab}}$ & 0.01 & 0.002 & 0.01 & 0.01 & 0.01 & 0.02 & 0.01 & 0.057 \\
\hline
\end{tabular}

AC: Treatment without Zilpaterol Hydrochloride $(\mathrm{ZH})$ in diet, animals had zero p.i.

${ }^{2}$ AZ: Treatment with $\mathrm{ZH}$ in diet. ZH only supplemented for the last 30 on feed, with four days withdrawal before slaughter; animals had zero p.i.

${ }^{3} A B$ :Grass-fed steers with 1-2 p.i.

${ }^{4} \mathrm{~B}$ : Grass-fed steers with 3-6 p.i.

a,b within a row with different superscripts differ significantly, MSE=Standard error of mean.

FAME=Fatty acid methyl ester/s 
with AC (Table 4). De Smet et al. (2004) reported a negative relationship between muscle fat level and P/S ratio, which support our results for the two grain-fed groups. However, muscle fat content of the $B$ group was lower than that of AC $(P<0.001)$, yet the P/S ration was similar. Wood et al. (2008) found that SFA decreased, MUFA increased and PUFA remained the same, although CLA increased when animals became fatter but also older. In agreement with our study, both French et al. (2000) and Elmore et al. (2004) recorded higher SFA levels, lower PUFA and no effect on MUFA or lower MUFA (Elmore) in grain-fed beef compared to grass-fed beef (or grass-silage). In the study of French et al. (2000), no differences in muscle fat existed, but silage fed animals in the study of Elmore et al. (2004) were fatter than grain-fed animals. Warren et al. (2008) showed that SFA did not change as total lipids changed, but there was an inverse relationship between PUFA proportions and total lipids, which is in contrast to the results of De Smet et al. (2004) and suggesting that factors other than muscle fat level played a role. These may include differences in the rate and extent of biohydrogenation of dietary PUFAs between grain and grass-fed animals (Noviandi et al., 2012).

Our study recorded P/S ratios between $0.13-0.27$, which agrees with Scollan et al. (2006) that the P/S ratio of beef is often as low as around 0.1 , while the recommended ratio for health purposes is above 0.4 (Enser et al., 1998).

In agreement with other studies (Enser et al., 1998; De la Fuente et al., 2009), the two grain-fed groups (AC and AZ) showed higher levels of total $n-6$ FAs $(P<0.001)$ and $n-6 / n-3$ ratios $(P<0.001)$ in all muscles compared with grass-fed groups, mainly as a result of higher levels of C18:2c9,12 n-6 $(P<0.001)$, the major n-6 PUFA (Table 4). According to the study reported by De la Fuente et al. (2009), the concentration of C18:2n-6 is greatest in cereals and oleaginous seeds, which constitute the principal components of concentrate diets. In contrast, major n-3 PUFAs; alpha linolenic acid (C18:3), and long n-3 FAs (ecosatrienoic (ETE C20:3); ecosapentaenoic (EPA C20:5) and docosapentaenoic (DPA C22:5)) were higher $(P<0.001)$ in the muscles of the grass- than grain-fed animals, and contributed to higher $(P<0.001)$ total $n-3$ FAs and lower $n-6 / n-3$ ratios $(<2: 1)$. Zilpaterol had no effect on long-chain $n-3$ FAs. A healthy diet is recommended to have $n-6 / n-3$ ratios of less than $2: 1$ (Simopoulos, 2010) which is much lower than the $8-14$ : 1 ratios recorded in the two grain-fed groups.

Rumenic acid (C18:2c9, t11; RA), the most important CLA isomer from a nutritional point of view, and arachidonic (C20:4c5) were higher in the muscles of grass- than grain-fed animals. Grass feeding increases the content of CLA due to biohydrogenation of PUFAs in the rumen, while grain feeding reduces the $\mathrm{pH}$ of the digestive system in ruminants, which inhibits the growth of the bacterium that produces CLA isomers (Warren et al., 2008; Daley et al., 2010; Noviandi et al., 2012). The content of RA was at least three times higher (up to $15 \mathrm{x}$ ) in the muscles of grass- compared to grain-fed animals in our study, which was higher than that reported in the review of Daley et al. (2009). RAis produced as an intermediate of ruminal biohydrogenation of linoleic acid (C18:2) and by endogenous synthesis from vaccenic acid (trans-11 C18:1; VA). According to Lock et al. (2009) RA has anticarcinogenic and antiartherosclerotic properties. VAis a major trans fatty acid in ruminant fats and according to Field et al. (2009) may have additional health benefits apart from those associated with its role as precursor of RA. The standard to analyse VA was unfortunately not used in the current study. The major trans fatty acids recorded in our study were C18:1t9 which was consistently higher in grain-fed muscles of both treatments (AC and AZ), while Gomez-Cortes et al. (2009) found no differences in milk of grain-fed vs. grass fed dairy ewes for this trans fatty acid, but higher values for C18:1t10. De Jong (2017) found that trans-fatty acid content of meat is generally low according to a survey done on cuts purchased at various retailers in South Africa.

Significantly higher percentages of saturated multi-branched C20:0 3, 7, 11, 15 tetramethylhexadecanoic acid (phytanic acid) were found in the muscles of grass-fed groups compared to that of grainfed groups (Table 4). Vetter and Schröder (2011) reported phytanic acid levels of 50-300 mg / $100 \mathrm{~g}$ lipids in grass-fed beef, while the highest levels recorded in the current study were between $700-850 \mathrm{mg} / 100 \mathrm{~g}$ lipid in the IMF of grass-fed steers. Higher levels of phytanic acid in grass-fed animals could be attributed to high chlorophyll content found in grass. According to Verhoeven et al. (1998), high levels of phytanic acid may result from the ingestion of appreciable quantities of free phytol in the diet of an animal, produced by hydrolysis of chlorophyll from grass. The AZ group recorded higher $(P<0.001)$ RA and phytanic acid levels than AC for BF muscle only, although the differences were not as large as the differences between grainand grass-fed groups. Likewise, age within the grass-fed groups did not have an effect on rumenic or phytanic acid levels.

Reports indicate that beta-agonists cause an increase in lipolysis and a decrease in lipogenesis (Mersmann, 1998). Likewise, in the current study zilpaterol samples recorded lower IMF values in the grainfed animals, therefore it was expected that zilpaterol would modify the fatty acid composition. Although Parr et al. (2014) showed evidence of triglyceride breakdown (higher serum NEFA levels) in zilpaterol treated animals, an earlier study by the same authors did not show any effects on fatty acid composition of IMF or 
sub-cutaneous fat of treated animals. Choi et al. (2013) and Dávila-Ramírez et al. (2017) also reported no or little effect of zilpaterol on fatty acid composition of beef and lamb, respectively. It is however, worth mentioning that zilpaterol increased the PUFA levels in two of the three muscles compared to AC. More specific, the increase in PUFA was mainly due an increase in $n-6$ PUFA levels, while similar levels of PUFA for the AB group, e.g. the LL and ST muscle was reflected in higher n-3 PUFA.

The differences in fatty acid composition among production systems in our study may have implications for human nutrition as was discussed in similar studies by Enser et al. (1998), Scollan et al. (2006), Warren et al. (2008) and Daley et al. (2010). Phytanic acid has health improving properties, including ability to inhibit the proliferation of prostate carcinoma cells in culture, and has potential effects on glucose and lipid metabolism in both humans and animals (Young et al., 2013). Conjugated linoleic acid (rumenic acid) and n-3 PUFA's are also associated with positive health effects. CLA is anticarcinogenic, protects against atheroscleorosis, may also play a role in the control of obesity and improve immune function. The $\mathrm{n}$ 3 PUFAs also have similar effects to CLA on human health (Whetsell et al., 2003; Daley et al., 2010; Young et al., 2013).

The atherogenicity index $(\mathrm{Al})$, which is an indicator for the risk of cardiovascular disease, was the highest in the IMF of B grass-fed LL and ST muscles (Table 4). Higher AI is indicative of high levels of cholesterol-elevating SFAs (C14:0, C16:0) observed in B grass-fed animals (Table 5). However, the Al of all the muscles across all the treatments could be considered favourable since it is assumed that an $\mathrm{Al}$ of below one is beneficial for human health (Pilarczyk \& Wójcik, 2015).

\section{Conclusions}

Most of fresh beef marketed in South Africa is produced under the production systems described by the four treatment groups in this study. In general, it can be concluded that production systems had a significant effect on chemical composition and fatty acid composition of the three muscles although the magnitude of these differences were often small. The muscle fat content varied between 1 and $1.5 \%$ with only AC LL muscles showing values of $>3 \%$. The actual amount of certain fatty acids present in the muscle tissue and the differences among treatments are therefore very small but could contribute to nutritional and health benefits on a micronutrient level. The low fat content of $A Z$ muscles suggests that the utilisation of zilpaterol in grain-fed systems will produce young slaughter (A-age) animals with the same fat content as older grassfed animals under South African production conditions. However, due to its effect as repartitioning agent, zilpaterol will produce muscle with slightly higher protein content than other beef. In agreement with previous studies, grass-fed beef recorded higher ratios of certain PUFA's with health benefit such as (the CLA-isomer RA and n-3 FAs) and also the branched chain SFA, phytanic acid, than muscles of grain-fed beef, irrespective of muscle. The fact that age variation between grass-fed groups in most cases had no effect is also worth noting. Zilpaterol treated muscles recorded higher levels of PUFA, but more specifically n-6 PUFA of LL and ST muscle. In addition, higher phytanic acid in BF muscle and higher RA (CLA) in ST and BF muscles over levels in grain-fed muscles without zilpaterol were recorded. Higher IMF content contributed to a higher MUFA in grain-fed muscles (AC) compared to grass-fed muscles (excluding BF) which indicated that carcass condition and not feeding regime as such may play a significant role in ratios of SFA, MUFA and PUFA.

\section{Acknowledgements}

The authors are grateful for the assistance offered by the personnel of the Agricultural Research Council - Animal Production Institute, Irene, with the experimental work and in the rearing and processing of experimental animals and carcasses. The Agricultural Research Council is acknowledged for use of facilities. Technology Human Resource Industry Program and the Red Meat Research Development Trust are acknowledged for financial support.

\section{Author's Contributions}

EM conducted the research as part of her PhD study, drafted and performed the technical preparation of the manuscript. PES devised the research idea. AH and PES supervised the study and revised the manuscript draft. All authors read and approved the final manuscript.

\section{Conflict of Interest Declaration}

There are no conflict of interests

\section{References}

Acocks, J.P.H., 1975. Veld Types of South Africa. In: Memoirs of the Botanical Survey of South Africa. Eds: Killick,D.J.B., Department of Agricultural Technical Services, Pretoria, South Africa. pp 39-40.

Anonymous, 2017a. Report of the Climate Monitoring Services of the Agricultural Research Council, Institute for Soil, Climate and Water. http://www.arc.agric.za/arc-iscw/Pages/Climate-Monitoring-Services.aspx (accessed on March 2014). 
Anonymous, 2017b. Freedom of information summary. Original new animal drug application NADA 141-258. Zilmax (zilpaterol hydrochloride) Type A medicated article for cattle fed in confinement for slaughter. http://www.fda.gov/downloads/AnimalVeterinary/Products/ ApprovedAnimalDrugProducts/FOIADrugSummaries/ucm051412.pdf. 2006. (accessed 13 December 2017).

Antonelo, D.S., Mazon, M.R., Nubiato, K.E.Z., Gómez, J.F.M., Brigida, D.J., Gomes, R.C., Netto, A.S., Leme, P.R. \& Silva, S.L., 2017. Effects of immunocastration and beta-adrenergic agonists on the performance and carcass traits of feedlot finished Nellore cattle. Animal 11, 2103-2110.

AOAC, 1990. Official methods of analysis, (15th ed.). Association of Official Analytical Chemists, Inc., Arlington, Virginia, USA.

Chilliard, Y., Ferlay, A., Rouel, J. \& Lamberet, G., 2003. A review of nutritional and physiological factors affecting goat milk lipid synthesis and lipolysis. J. Dairy Sci. 86, 1751-1770.

Choi, C.B., Jung, K.K., Chung, K.Y., Yang, B.S., Chin, K.B., Suh, S.W., Oh, D.H., Jeon, M.S., Baek, K.H., Lee, S.O., Kim, S.I., Lee, Y.H., Yates, D.A., Hutcheson, J.P. \& Johnson, B.J.,2013. Administration of zilpaterol hydrochloride alters feedlot performance, carcass characteristics, muscle, and fatprofiling in finishing Hanwoo steers. Livest. Sci.157, 435-441.

Daley, C.A, Abbott, A., Doyle, P.S., Nader, G.A. \& Larson, S., 2010. A review of fatty acid profiles and antioxidant content in grass-fed and grain-fed beef. J. Nutr. 9, 10.

Dávila-Ramírez, J.L., Avendaño-Reyes, L., Macías-Cruz, U., Peña-Ramos, E.A., Islava-Lagarda, Y.,Zamorano-García, L., Valenzuela-Melendres, M., Camou, J.P.\& González-Ríos, H., 2017. Fatty acid composition and physicochemical and sensory characteristics of meat from ewe lambs supplemented with zilpaterol hydrochloride and soybean oil. Anim. Prod. Sci. 57, 767-777.

Dawson, J.M., Buttery, P.J., Gilt, M. \& Beever, D.E., 1990. Muscle composition of steers treated with the beta-agonist, cimaterol. Meat Sci. 28, 289-297.

De Freitas, A., Lobato, J.F.P., Cardoso, L.L., Tarouco, J.U., Vieira, R.M., Dillenburg, D.R. \& Castro, I., 2014. Nutritional composition of the meat of Hereford and Braford steers finished on pastures or in a feedlot in Southern Brazil. Meat Sci. 96, 353-360.

De Jong, B.T., 2017 Analysis of the trans fatty acid content of beef from major retailers in Gauteng province. M.Sc. (Agric.) Animal Science Unesis, University https://repository.up.ac.za/bitstream/handle/2263/60873/DeJong_Analysis_2017.pdf?sequence=1\&isAllowed=y (accessed 13 December 2017).

De la Fuente, J., Díaz, M.T., Álvarez, I., Oliver, M.A., Font I Furnols, M., Sañudo, C., Campo, M.M., Montossi, F., Nute, G.R. \& Cañeque, V., 2009. Fatty acid and vitamin E composition of intramuscular fat in cattle reared in different production systems. Meat Sci. 82, 331-337.

De Smet, S., Raes, K. \& Demeyer, D., 2004. Meat fatty acid composition as affected by fatness and genetic factors: A review. Anim. Res. 53, 81-98.

Elmore, J.S., Warren, H.E., Mottram, D.S., Scollan, N.D., Enser, M., Richardson, R.I., et al. (2004). A comparison of the aroma of volatiles and fatty acid compositions of grilled beef muscle from Aberdeen Angus and Holstein-Friesian steers fed diets based on silage or concentrates. Meat Sci. 68, 27-33.

Enser, M., Hallet, K.G., Hewett, B., Fursey, G.A., Wood, J.A.D \& Harrington, G., 1998. Fatty acid content and composition of UK beef and lamb muscle in relation to production system and implications for human nutrition. Meat Sci. 49, 329-341.

Field, C. J., Blewett, H. H., Proctor, S., \& Vine, D., 2009. Human health benefits of vaccenic acid. App. Phys. Nutr. Metab. 34, 979-991.

Folch, J., Lees, M. \& Stanley, G.H.S., 1957. A simple method for the isolation and purification of total lipids from animal tissues. J. Biol. Chem. 226, 497-509.

French, P.C., Stanton, C., Lawless, F., O'Riordan, G., Monahan, F.J., \& Caffrey, P.J., 2000. Fatty acid composition including conjugated linoleic acid, of intramuscular fat from steers offered grazed grass, grass silage or concentrate-based diets. J. Anim. Sci. 78, 2849-2855.

Government Notice No. R.342 of 19 March 1999. Regulations regarding the classification and marking of meat. Government Gazette of the Republic of South Africa, 19 March 1999.

Harper, G.S. \& Pethick, D.W., 2004. How might marbling begin? Aust J Exp Agric.44, 653-662.

Johnson B.J., Ribeiro, F.R.B. \& Beckett, J.L., 2013. Application of growth technologies in enhancing food security and sustainability. Animal Frontiers 3, 8-13.

Kellermeier, J.D., Tittor, A.W,, Brooks, J.C., Galyean, M.L., Yates, D.A., Hutcheson, J.P., Nicholas, W.T., Streeter, M.N., Johnson, B.J. \& Miller, M.F., 2009. Effects of zilpaterol hydrochloride with or without an estrogen-trenbolone acetate terminal implant on carcass traits, retail cutout, tenderness, and muscle fiber diameter in finishing steers. J. Anim. Sci. 87, 3702-3711.

Kuiper, H.A., Noordam, M.Y., van Dooren-Flipsen, M.M.H., Schilt, R. \& Roos, A.H., 1998. Illegal use of beta-adrenergic agonists: European Community. J.Anim. Sci. 76,195-207.

Lean, I.J., Thompson, J.M. \& Dunshea,FR., 2014.A meta-analysis of zilpaterol andractopamine effects on feedlot performance, carcass traits and shear strength of meat in cattle.PLoS ONE 9, e115904.

Leheska, J. M., Montgomery, J.L., Krehbiel, C.R., Yates, D.A., Hutcheson, J.P., Nichols, W.T., Streeter, M., Blanton, JR.jr. \&Miller, M.F., 2009. Dietary zilpaterol hydrochloride. II. Carcass composition and meat palatability of beef cattle. J. Anim. Sci. 87, 1384-1393. 
Lock, A. L., Kraft, J., Rice, B. H. \& Bauman, D. E. 2009. Biosynthesis and biological activity of rumenic acid: A natural CLA isomer. In:, Trans fatty acids in human nutrition (Eds. F. Destaillats, J. L. Sébédio, F. Dionisi, \& J. M. Chardigny) The Oily Press,Bridgwater, UK. pp. 195-230.

Mersmann, H. 1998. Overview of the effects of beta-adrenergic receptor agonists on animal growth including mechanisms of action. J. Anim. Sci.76, 160-172.

Miller, E.K., Chung, K.Y., Hutcheson, J.P., Yates, D.A., Smith, S.B. \& Johnson, B.J., 2012. Zilpaterol hydrochloride alters abundance of beta-adrenergic receptors in bovine muscle cells but has little effect on de novo fatty acid biosynthesis in bovine subcutaneous adipose tissue explants. J. Anim. Sci. 90, 1317-1327.

Noviandi, C.T., Ward, R.E., ZoBell, D.R., Stott, R.D., Waldron, B.L., Peel, M.D. \& Eun, J.-S., 2012. Fatty acid composition in adipose tissue of pasture- and feedlot-finished beef steers. Prof. Anim. Scientist. 28, 184-193.

Park,Y., Albright, K.J., Cai, Z.Y. \& Pariza, W.,2001. Comparison of methylation procedures for conjugated linoleic acid and artifact formation by commercial (trimethylsilyl) diazomethane. J. Agric. Food Chem. 49, 1158-1164.

Parr, S.L., Brown, T.R., Ribeiro, F.R.B., Chung, K.Y., Hutcheson, J.P., Blackwell, B.R., Smith, P.N. \& Johnson, B.J., 2014. Biological responses of beef steers to steroidal implants and zilpaterol hydrochloride. J. Anim. Sci. 92, 3348-3363.

Pethick, D.W.A., Harper, G.S.A. \& Oddy, V.H.A., 2004. Growth, development and nutritional manipulation of marbling in cattle: A review. Aust. J. Exp. Agric. 44, 705-715.

Pflanzer, S.B. \& de Felício, P.E., 2011. Moisture and fat content, marbling level and colour of boneless rib cut from Nellore steers varying in maturity and fatness. Meat Sci. 87, 7-11.

Pilarczyk, R. \& Wójcik, K., 2015. Fatty acids profile and health lipid indices in the longissimus lumborum muscle of different beef cattle breeds reared under intensive production systems. Acta Sci. Pol. Zootech.14, 109-126.

Payne, R.W, Murray, D.A., Harding, S.A., Baird, D.B. \& Soutar, D.M., 2007. An Introduction to GenStat for Windows ${ }^{8}$ (10th ed.). VSN International, Hemel Hempstead, UK.

Ruiz-Núñez, B., Dijck-Brouwer, D.A.J. \& Muskiet, F.A.J., 2016. The relation of saturated fatty acids with low-grade inflammation and cardiovascular disease. J. Nutr. Biochem. 36, 1-20.

Schönfeldt, H.C., Naudé, R.T., \& Boshoff, E., 2010. Effect of age and cut on the nutritional content of South African beef. Meat Sci. 86, 674-683.

Scollan, N., Hocquette, J.F., Nürnberg, K., Dannenberger, D., Richardson, I. \& Moloney, A., 2006. Innovations in beef production systems that enhance the nutritional and health value of beef lipids and their relationship with meat quality. Meat Sci. 74, 17-33.

Shirouchi, B., Albrecht, E., Nuernberg, G., Maak, S., Samadmanivong, O., Nakamura, Y., Sato, M., Gotoh, T. \& Nuernberg. K., 2013. Fatty acid profiles and adipogenic expression of various fat depots in Japanese Black and Holstein cattle. Meat Sci. 96,157-164.

Silva, C.C.G, Rego, O.A., Simões, E.R.E. \& Rosa, H.J.D., 2010. Consumption of high energy maize diets is associated with increased soluble collagen in muscle of Holstein bulls. Meat Sci. 86, 753-757.

Smith, S.B., Gill, C.A., Lunt, D.K. \& Brooks, M.A., 2009. Regulation of fat and fatty acid composition in beef cattle. AsianAust. J. Anim. Sci. 22, 1225-1233.

Simopoulos, A.P., 2010. The omega-6/omega-3 fatty acid ratio: Health implications. Oilseeds \& fats, Crops Lipids. 17, 267-275.

Strydom, P.E., Frylinck, L., Montgomery, J.L. \& Smith, M.F., 2009. The comparison of three beta-agonists for growth performance, carcass characteristics and meat quality of feedlot cattle. Meat Sci. 81, 557-564.

Verhoeven, N.M., Wanders, R.J.A., Poll-The, B.T., Saudubray, J.M., \& Jakobs, C., 1998. The metabolism of phytanic acid and pristanic acid in man: A review. J. Inher. Metab. Dis. 21, 697-728.

Vetter, W. \& Schröder, M., 2011. Phytanic acid-a tetramethyl-branched fatty acid in food. Lipid Technol. 23, $175-178$.

Warren, H.E., Scollan, N.D., Enser, M., Hughes, S.I., Richardson, R.I. \& Wood, J.D., 2008. Effects of breed and a concentrate or grass silage diet on beef quality in cattle of 3 ages. II: Animal performance, carcass quality and muscle fatty acid composition. Meat Sci. 78, 256-269.

Whetsell, M.S., Rayburn, E.B. \& Lozier, J.D., 2003. Human health effects of fatty acids in beef. Fact sheets. West Virginia University extension services. www.wvu.edu/ agexten/forglvst/humanhealth.pdf. (accessed 6 October 2016).

Wood, J.D., Richardson, R.I, Nute, G.R., Kasapidou, E., Sheard, P.R. \& Enser, M., 2003. Effects of fatty acids on meat quality: A review. Meat Sci. 66, 21-23.

Wood, J.D., Enser, M., Fisher, A.V., Nute, G.R., Richardson, P.R.R.I., Hughes, S.I. \& Whittington F.M. Effects of breed and a concentrate or grass silage diet on beef quality in cattle of 3 ages. I: Animal performance, carcass quality and muscle fatty acid composition Meat Sci. 78, 256-269.

Young, J.F., Therkildsen, M., Ekstrand, B., Che, B.N., Larsen, M.K., Oksbjerg, N. \& Stagsted, J., 2013. Novel aspects of health promoting compounds in meat. Meat Sci. 95, 904-911. 